\title{
Analysis of the Break-even and Load Index of Water Resources in Beijing
}

\author{
Dan $\mathrm{Wu}^{1, *}$ Yanlai Jin ${ }^{1}$ Yongkuan Wang ${ }^{1}$ Hao Shen ${ }^{1}$ \\ ${ }^{1}$ School of Economics and Management, North China University of Technology, Beijing 100144, China \\ *Corresponding author.Email: wu_daniel@163.com
}

\begin{abstract}
The change of water resources quantity and water resources supply are elaborated in this paper to analyze water resources in Beijing. On this basis, the profit-loss amount and the profit-loss rate of water resources in Beijing are calculated by using break-even analysis. The water resource load index method is also employed to calculate the population and economic scale that can be supported by water resources in Beijing, and then reveal the relationship between water resources, population and economic development in Beijing. The results show that during the period from the 10th five-year plan to the 13th five-year plan, the total amount of water resources and the water resources per capita in Beijing have increased on the whole, but they are far below the internationally recognized warning line of extreme water shortage. The water resources in Beijing are in a state of "break-even", among which the surface water resources are in an alternating state of "break-even - surplus - break-even", while the groundwater resources are in a state of "break-even" to "surplus". The load index of water resources in Beijing continues to improve, and the population-economic scale of load per unit of water resources has reached medium level.
\end{abstract}

Keywords: Beijing, Water resources, Supply, Break-even, Load index.

\section{INTRODUCTION}

Water resource is a strategic resource for sustainable economic and social development of Beijing, which provides a guarantee for economic and industrial development, residents' life and environmental protection. Accelerating the transformation and upgrading of industrial structure in the process of modernization in Beijing is conducive to improving the efficiency of intensive utilization of water resources. However, the economic and social development of Beijing is still facing the problems of intensified contradiction

*Fund: Project of Beijing Undergraduate Innovation and Entrepreneurship Training Program in 2021, "Research on Coordination Evaluation of Economic Development and Water Resources Utilization in Beijing" (Grant No. :

108051360021XN216/004); Talent Project of North China University of Technology, "Research on Evaluation System of Resource Energy Consumption Management Performance and Collaborative Governance Capacity in Beijing-Tianjin-Hebei Region from the Perspective of Science and Technology Innovation" (Grant No. : 107051360021XN083/055); Beijing Natural Science Foundation Project "Research on the Bidirectional Optimization Adaptation of Water Resources and Industrial Structure in Beijing-Tianjin-Hebei Collaborative Development" (Grant No. 9202005). between supply and demand of water resources and increasing pressure of supply and demand of water resources. Therefore, it is urgent to conduct in-depth research on the water resources of surface water and groundwater, the population supported by water resources and the economic scale in Beijing, so as to provide decision-making support for the optimal allocation of water resources in Beijing. At present, the research on the evaluation of water resources utilization in Beijing mainly focuses on three aspects: the risk assessment of water resources supply and demand in Beijing [1-5], the evaluation of water resources carrying capacity in Beijing [6-7], and the coordination evaluation of water resources and economic development in Beijing [8-13]. However, few scholars have analyzed the break-even of water resources in Beijing during different planning periods and evaluated the load capacity of water resources on population and economic development in Beijing. Therefore, the break-even and water resource load index are used to analyze the water resource breakeven and water resource load index of Beijing in different planning periods. 


\section{CHANGES OF WATER RESOURCES IN BEIJING}

\subsection{Change of Water Resource Quantity}

With a large population and a booming economy, Beijing faces the plight of a relative shortage of water resources, both in total and available, which leads to low per capita water resources. Therefore, Beijing has become the province with the lowest per capita water resources in China, and it is a resource-

Table 1. Changes of water resources in Beijing during the 10th five-year plan to the 13th five-year plan

\begin{tabular}{|c|c|c|c|c|}
\hline & $\begin{array}{l}\text { Total } \\
\text { resources }\end{array}$ & $\begin{array}{l}\text { Surface } \\
\text { resources }\end{array}$ & $\begin{array}{l}\text { Groundwater } \\
\text { resources }\end{array}$ & $\begin{array}{l}\text { Water resources } \\
\text { per capita }\end{array}$ \\
\hline Planning period & $\begin{array}{lr}\text { Average } & \text { value } / 100 \\
\text { million } & \text { cubic } \\
\text { meters } & \\
\end{array}$ & $\begin{array}{lr}\text { Average } & \text { value } / 100 \\
\text { million } & \text { cubic } \\
\text { meters } & \\
\end{array}$ & $\begin{array}{lr}\text { Average } & \text { value/100 } \\
\text { million } & \text { cubic } \\
\text { meters } & \\
\end{array}$ & $\begin{array}{l}\text { Average } \\
\text { value/cubic meter }\end{array}$ \\
\hline $\begin{array}{l}\text { 10th five-year plan } \\
\text { period }\end{array}$ & 19.65 & 6.96 & 16.04 & 134.37 \\
\hline $\begin{array}{l}11 \text { th five-year plan } \\
\text { period }\end{array}$ & 25.00 & 8.21 & 19.69 & 141.64 \\
\hline $\begin{array}{l}\text { 12th five-year plan } \\
\text { period }\end{array}$ & 27.64 & 10.47 & 20.59 & 131.76 \\
\hline $\begin{array}{l}\text { 13th five-year plan } \\
\text { Period }\end{array}$ & 31.25 & 12.23 & 24.55 & 144.46 \\
\hline
\end{tabular}

a Note: The "13th five-year plan" period mainly refers to statistical data from 2016 to 2019 , the same below.

According to "Table 1", the mean amount of water resources in Beijing increased from the 10th five-year plan to the 13th five-year plan, with an increase rate of $59 \%$. However, during the 13th fiveyear plan period, the average amount of water resources in Beijing is only 3.125 billion cubic meters. Among them, the average growth rate of surface water resources was faster than that of groundwater resources, with an increase rate of $76 \%$ and $53 \%$ respectively. During the 10 th five-year plan period, the average amount of groundwater resources was 2.30 times that of surface water resources, and decreased to 2.01 times in the 13th five-year plan period. As for the per capita water resources in Beijing, from the 10th five-year plan period to the 13th five-year plan period, it showed an overall growth trend, from 134.37 cubic meters to 144.46 cubic meters, but it is far below the internationally recognized warning line of 500 cubic meters for extreme water shortage. By 2019, per capita water resources in Beijing will drop to 114.23 cubic meters.

\subsection{Changes in Water Supply}

The water supply of Beijing mainly includes surface water supply, groundwater supply, and other water supply (including water from south to north, reclaimed water, seawater desalination, etc.). From the 10th five-year plan period to the 13th five-year plan period, the average water supply in Beijing increased continuously, from 3.552 billion cubic deficient megacity. From 2000 to 2019, the fluctuation pattern of the total water resources in Beijing has changed significantly, from 1.686 billion cubic meters in 2000 to 3.95 billion cubic meters in 2012, and then decreased to 2.46 billion cubic meters in 2019. From the 10th five-year plan period to the 13th five-year plan period, the change of water resources in Beijing is relatively significant, as shown in "Table 1".

meters to 3.92 billion cubic meters. The change of water resources supply in Beijing during the 10th five-year plan to the 13th five-year plan is shown in "Table 2". 
Table 2. Changes of water resources supply in Beijing during the 10th five-year plan to the 13th five-year plan

\begin{tabular}{|c|c|c|c|c|c|c|}
\hline & $\begin{array}{l}\text { Surface } \\
\text { water supply }\end{array}$ & $\begin{array}{l}\text { Proportion } \begin{array}{r}\text { of } \\
\text { surface water } \\
\text { supply }\end{array} \\
\end{array}$ & $\begin{array}{l}\text { Groundwater } \\
\text { supply }\end{array}$ & $\begin{array}{l}\text { proportion of } \\
\text { groundwater } \\
\text { supply }\end{array}$ & $\begin{array}{l}\text { Other water } \\
\text { supply }\end{array}$ & $\begin{array}{l}\text { proportion of } \\
\text { Other water } \\
\text { supply }\end{array}$ \\
\hline period & $\begin{array}{l}\text { Average } \\
\text { value/100 } \\
\text { million cubic } \\
\text { meters }\end{array}$ & Average value/\% & $\begin{array}{l}\text { Average } \\
\text { value/100 } \\
\text { million cubic } \\
\text { meters }\end{array}$ & $\begin{array}{l}\text { Average } \\
\text { value/\% }\end{array}$ & $\begin{array}{l}\text { Average } \\
\text { value/100 } \\
\text { million cubic } \\
\text { meters }\end{array}$ & $\begin{array}{l}\text { Average } \\
\text { value/\% }\end{array}$ \\
\hline $\begin{array}{l}\text { 10th five-year } \\
\text { plan period }\end{array}$ & 8.62 & 24.13 & 25.72 & 72.47 & 1.18 & 3.40 \\
\hline $\begin{array}{l}\text { 11th five-year } \\
\text { plan period }\end{array}$ & 6.45 & 18.44 & 22.89 & 65.50 & 5.63 & 16.06 \\
\hline $\begin{array}{l}\text { 12th five-year } \\
\text { plan period }\end{array}$ & 8.83 & 23.95 & 19.82 & 53.96 & 8.14 & 22.09 \\
\hline $\begin{array}{l}\text { 13th five-year } \\
\text { plan period }\end{array}$ & 12.77 & 31.98 & 16.37 & 41.16 & 10.71 & 26.86 \\
\hline
\end{tabular}

"Table 2" shows that from the 10th five-year plan period to the 13th five-year plan period, the total surface water supply in Beijing increased slowly, with an increase rate of $48 \%$. The average proportion of surface water supply in Beijing has increased by $7.85 \%$. In addition, the total amount of groundwater supply in Beijing decreased by $36 \%$. The average proportion of groundwater supply in Beijing has dropped by 31.31 percentage points. Other water supplies in Beijing increased rapidly overall, with an average increase of 9.08 times. The average proportion of other water supplies in Beijing has increased by 23.46 percentage points. The comparison of surface water supply, groundwater supply and other water supply shows that the average amount of groundwater supply in Beijing is the largest during the 10th five-year plan period to the 13th five-year plan period, but the multiple between the average amount of groundwater supply and the average amount of surface water supply decreases slowly, from 2.98 times to 1.28 times. At the same time, the multiples of the mean water supply of groundwater and other water supplies decreased rapidly, from 21.80 to 1.53 times.

\section{ANALYSIS OF WATER RESOURCES BREAK-EVEN IN BEIJING}

There is a serious imbalance between the supply and demand of water resources in Beijing and the total amount of water resources is not enough to meet the water supply. The contradiction between the shortage of water resources and the rapid development of economy and society in Beijing leads to the overdependence of groundwater resources in Beijing. In view of the change of the total amount of water resources and water supply in Beijing, the break-even analysis method was adopted to analyze the break-even of water resources in Beijing during the 10th five-year plan period and the 13th five-year plan period, as shown in "Table 3". 
Table 3. Analysis on the break-even of Water Resources in Beijing during the 10th five-year plan Period and the Thirteenth Five-year plan Period

\begin{tabular}{|c|c|c|c|c|c|c|c|}
\hline \multirow{2}{*}{\multicolumn{2}{|c|}{$\begin{array}{l}\text { Planning } \\
\text { period }\end{array}$}} & $\begin{array}{l}\text { Total break- } \\
\text { even of water } \\
\text { resources }\end{array}$ & $\begin{array}{l}\text { Total break- } \\
\text { even ratio of } \\
\text { water } \\
\text { resources }\end{array}$ & $\begin{array}{l}\text { Total break- } \\
\text { even of } \\
\text { surface water } \\
\text { resources }\end{array}$ & $\begin{array}{l}\text { Total break- } \\
\text { even ratio of } \\
\text { surface water } \\
\text { resources }\end{array}$ & $\begin{array}{l}\text { Total break- } \\
\text { even of } \\
\text { groundwater } \\
\text { resources }\end{array}$ & $\begin{array}{l}\text { Total break- } \\
\text { even ratio of } \\
\text { groundwater } \\
\text { resources }\end{array}$ \\
\hline & & $\begin{array}{l}\text { Average } \\
\text { value/100 } \\
\text { million cubic } \\
\text { meters }\end{array}$ & $\begin{array}{l}\text { Average } \\
\text { value/\% }\end{array}$ & $\begin{array}{l}\text { Average } \\
\text { value/100 } \\
\text { million cubic } \\
\text { meters }\end{array}$ & $\begin{array}{l}\text { Average } \\
\text { value/\% }\end{array}$ & $\begin{array}{l}\text { Average } \\
\text { value/100 } \\
\text { million cubic } \\
\text { meters }\end{array}$ & $\begin{array}{l}\text { Average } \\
\text { value/\% }\end{array}$ \\
\hline $\begin{array}{l}10 \text { th } \\
\text { year } \\
\text { period }\end{array}$ & $\begin{array}{l}\text { five- } \\
\text { plan }\end{array}$ & -15.87 & -83.72 & -1.66 & -29.59 & -9.68 & -61.46 \\
\hline $\begin{array}{l}11 \text { th } \\
\text { year } \\
\text { period }\end{array}$ & $\begin{array}{l}\text { five- } \\
\text { plan }\end{array}$ & -9.97 & -43.82 & 1.75 & 15.58 & -3.20 & -18.01 \\
\hline $\begin{array}{l}12 \text { th } \\
\text { year } \\
\text { period }\end{array}$ & $\begin{array}{l}\text { five- } \\
\text { plan }\end{array}$ & -9.14 & -39.76 & 1.64 & 4.75 & 0.77 & 1.29 \\
\hline $\begin{array}{l}13 \text { th } \\
\text { year } \\
\text { period }\end{array}$ & $\begin{array}{l}\text { five- } \\
\text { plan }\end{array}$ & -8.58 & -30.83 & -0.55 & -11.39 & 8.18 & 32.22 \\
\hline
\end{tabular}

\subsection{Changes in Break-even of Water Resources}

"Table 3" shows that during the 10th five-year plan period and the 13th five-year plan period, the water resources of Beijing presents a "break-even" state. However, the mean absolute value of total water resources break-even in Beijing has been shrinking continuously from 1.587 billion cubic meters to 858 million cubic meters, with a decrease of $45.94 \%$. The surface water resources are in an alternating state of "break-even - surplus - breakeven". During the 10th five-year plan period, the absolute value of the average break-even of Beijing's surface water resources was 166 million cubic meters. During the 11th five-year plan period and the 12th five-year plan period, Beijing's surface water resources changed from break-even to surplus, but the average surplus of Beijing's surface water resources decreased from 175 million cubic meters to 164 million cubic meters. During the 13th five-year plan period, Beijing's surface water resources turned to break-even again, and the absolute value of the average break-even of surface water resources was 55 million cubic meters. The groundwater resources in Beijing have changed from "break-even" to "surplus" state. During the 10th five-year plan period and the 11th five-year plan period, the mean absolute value of break-even of groundwater resources in Beijing decreased from 968 million cubic meters to 320 million cubic meters. From the 12th five-year plan period to the 13th five-year plan period, the groundwater resources in Beijing have changed from break-even to surplus. The average surplus of groundwater resources has continued to expand from 77 million cubic meters to 818 million cubic meters, an increase of 10.6 times.

\subsection{Change of Break-even Ratio of Water Resources}

"Table 3" shows that from the 10th five-year plan period to the 13th five-year plan period, the total break-even ratio of water resources in Beijing continued to shrink, with the absolute value of its mean value dropping from $83.72 \%$ to $30.83 \%$, a decline of 52.89 percentage points. The break-even ratio of surface water resources in Beijing is generally reduced. During the 10th five-year plan period, the absolute value of the mean break-even ratio of surface water resources was $29.59 \%$. From the 12th five-year plan period to the 12th five-year plan period, the average surplus ratio of surface water resources dropped from 15.58 percent to 4.75 percent, a decrease of 10.83 percentage points. During the 13th five-year plan period, the average break-even ratio of surface water resources is $11.39 \%$. From the 10th five-year plan period to the 13th five-year plan period, the mean absolute value of the break-even ratio of surface water resources decreased by 18.2 percentage points. The break-even ratio of groundwater resources in Beijing is decreasing rapidly and entering the period of surplus of groundwater resources. From the 10th five-year plan period to the Eleventh Five-year plan period, the mean absolute value of break-even ratio of groundwater resources decreased from $61.46 \%$ to $18.01 \%$, a decrease of 43.45 percentage points. From the 12th five-year plan period to the 13th five-year plan period, the average surplus rate of groundwater resources increased from $1.29 \%$ to $32.22 \%$. 


\section{WATER RESOURCE LOAD INDEX OF BEIJING}

\subsection{Calculation Method of Water Resource Load Index}

$$
C(t)=K(t) \sqrt{P(t) \cdot G(t)} / W(t)
$$

In Formula (1), ${ }^{C(t)}$ is the load index of water resources in Beijing in the period ${ }^{t} ;{ }^{P(t)}$ is the population size (ten thousand people) of Beijing in the period ${ }^{t} ; G(t)$ is the gross domestic product (100 million yuan) of Beijing in the period ${ }^{t} ;{ }^{W(t)}$ represents the total water resources $(100$ million

$$
K(t)=\left\{\begin{array}{lc}
1.0 & R(t) \leq 200 \\
1.0-0.1(R(t)-200) / 200 & 200<R(t) \leq 400 \\
0.9-0.2(R(t)-400) / 400 & 400<R(t) \leq 800 \\
0.7-0.2(R(t)-800) / 800 & 800<R(t) \leq 1600 \\
0.5 & R(t)>1600
\end{array}\right.
$$

In Formula (2), $R(t)$ is the precipitation in Beijing (mm) during the ${ }^{t}$ period.

The water resource load index of Beijing reflects the population-economic scale of the water resource load per unit of Beijing. The lower the index is, the lower the degree of population-economic scale of Beijing's water resource load is, and there is still some room for improvement of Beijing's water resource load index. The classification of water resource load index is shown in "Table 4".

Table 4. Classification of water resource load index

\begin{tabular}{|l|l|l|}
\hline Rank & $\begin{array}{l}\text { water } \\
\text { resource load } \\
\text { index }\end{array}$ & $\begin{array}{l}\text { population-economic scale of } \\
\text { the water resource load per unit }\end{array}$ \\
\hline I & $>10$ & very high \\
\hline II & $5-10$ & high \\
\hline III & $2-5$ & medium \\
\hline IV & $1-2$ & relatively low \\
\hline V & $<1$ & low \\
\hline
\end{tabular}

The water resource load index of Beijing is mainly expressed by the population and economic scale that can be supported by the water resources of Beijing, which reflects the relationship between the water resources of Beijing and the population and economic development. The formula can be expressed as

cubic meters) of Beijing in the period ${ }^{t} ; K(t)$ is the coefficient related to precipitation in Beijing in the period of ${ }^{t}$, which can be expressed by the formula below.

\subsection{Calculation of Water Resource Load Index}

According to Formula (1) and (2), the change of water resource load index of Beijing in different periods can be calculated, as shown in "Table 5".

Table 5. Water resource load index of Beijing in different periods

\begin{tabular}{|l|l|l|l|l|l|}
\hline period & $\begin{array}{l}\text { water resource load } \\
\text { index }\end{array}$ & period & $\begin{array}{l}\text { water resource load } \\
\text { index }\end{array}$ & period & $\begin{array}{l}\text { water resource } \\
\text { load index }\end{array}$ \\
\hline 2000 & 1.09 & 2011 & 1.76 & 10th five-year plan period & 1.21 \\
\hline 2001 & 1.03 & 2012 & 1.15 & 12th five-year plan period & 1.54 \\
\hline 2002 & 1.37 & 2013 & 2.22 & 12th five-year plan period & 2.04 \\
\hline
\end{tabular}




\begin{tabular}{|l|l|l|l|l|l|}
\hline 2003 & 1.28 & 2014 & 2.94 & 13th five-year plan Period & 2.17 \\
\hline 2004 & 1.17 & 2015 & 2.13 & & \\
\hline 2005 & 1.22 & 2016 & 1.64 & & \\
\hline 2006 & 1.43 & 2017 & 2.10 & & \\
\hline 2007 & 1.45 & 2018 & 1.83 & & \\
\hline 2008 & 1.01 & 2019 & 3.01 & & \\
\hline 2009 & 1.91 & $2000-$ & 1.69 & & \\
\hline 2010 & 1.91 & & & & \\
\hline
\end{tabular}

According to "Table 5", the fluctuation of the water resource load index in Beijing has increased from 2000 to 2019. In 2008, the water resource load index was the lowest, which was only 1.01. In 2013, the average water resource load index exceeded 2.0. In 2019, the average water resource load index exceeded 3.0. During the period from the 10th fiveyear plan to the 13th five-year plan, the average value of the water resource load index in Beijing continued to increase, with an increase rate of $79.34 \%$. According to the classification of water resource load index in "Table 4", the degree of populationeconomic scale of the water resource load per unit in Beijing has reached medium level.

\section{CONCLUSION}

During the period from the 10th five-year plan to the 13th five-year plan, the total amount of water resources in Beijing increased. Although the amount of groundwater resources exceeded that of surface water resources, the latter increased faster than the former. Per capita water resources have increased on the whole, far below the internationally recognized warning line of extreme water shortage. The water supply of surface water in Beijing increased slowly, the water supply of underground water decreased, and other water supply increased rapidly. The multiples of groundwater supply and surface water supply decreased slowly, so did the multiples of groundwater supply and other water supply. The water resources in Beijing are in a state of "breakeven", among which the surface water resources are in an alternating state of "break-even - surplus break-even", while the groundwater resources are in a state of "break-even" to "surplus". The total breakeven ratio of water resources, surface water resources and groundwater resources in Beijing are shrinking rapidly, ushering in the surplus period of groundwater resources. The average value of water resource load index in Beijing continues to improve, and the population-economic scale of load per unit has reached medium level.

\section{AUTHORS' CONTRIBUTIONS}

Dan $\mathrm{Wu}$ is responsible for experimental design and writing the manuscript, Yanlai Jin, Yongkuan Wang, Hao Shen are responsible for analysed data and writing the manuscript.

\section{REFERENCES}

[1] Wan Wenhua, Yin Junhan, Zhao Jianshi, et al. Sustainability evaluation of Beijing water deployment model before and after South-toNorth Water Diversion [J]. South-to-North Water Transfers and Water Science \& Technology, 2016, 14(02):62-69. (in Chinese)

[2] Guan Zhuojin, Ma Zhijie, Huang Lihua, et al. Groundwater variation trend model and water balance analysis in Beijing [J]. China Water Resources, 2016(03):29-31. (in Chinese)

[3] Qin Ling, Du Pengfei, Zheng Yu. Research on the development trend of water resources utilization and the balance of supply and demand in Beijing in 2049 [J]. Beijing City Planning \& Construction Review, 2012(03):4549. (in Chinese)

[4] Sun Hong, Mi Feng, Tian Minghua, et al. Risk Assessment of Water Supply and Demand for Urban Greening in Beijing City [J]. Bulletin of Soil and Water Conservation, 2014, 34(05):153157. (in Chinese)

[5] Liu Jiangxia. Discussion on the future water supply guarantee plan in Beijing $[\mathrm{J}]$. Haihe Water Resources, 2018(03):4-7. (in Chinese)

[6] Shen Yingchun, Yang Haochen. A Research on Water Resource Carrying Capacity of Beijing from the View of Sustainable Development [J]. Social Science of Beijing, 2010(06):20-23. (in Chinese) 
[7] Yu Haozhe, Li Lijuan, Li Jiuyi. Evaluation of water resources carrying capacity in the BeijingTianjin-Hebei Region based on quantity-qualitywater bodies-flow $[\mathrm{J}]$. Resources Science, 2020,42(02):358-371. (in Chinese)

[8] Wu Dan, Wang Hongji, Liu Shuai. Analysis of the correlation between Beijing's economic development and water resources consumption and utilization $[\mathrm{J}]$. China Collective Economy, 2019(11):32-33. (in Chinese)

[9] Wu Dan, Kang Xue. Evaluation of decoupling Beijing's economic development and water resources consumption and utilization $[\mathrm{J}]$. China Collective Economy, 2019(14):28-29. (in Chinese)

[10] Wu Dan, Xu Heyan. Evaluation on the Decoupling Trend and Efficiency of Water Resource Utilization of Economic Development in Beijing $[\mathrm{J}]$. Science Technology And Industrial, 2018,18(11):33-38. (in Chinese)

[11] Zhang Honglei, Zhao Liming, Zhang Xuehua. Evaluation Index System and Method of Urban Green Water Utilization - A Case Study of Peking, Shanghai and Tianjin [J]. Journal of Tianjin University (Social Sciences), 2017,19(02):113- 118. (in Chinese)

[12] Qiao Hongmin, Li Weiqing, He Zhongwei. Studying on the Beijing Agricultural Utilization of Water Resources [J]. Science Technology And Industrial, 2016,16(07):11-14. (in Chinese)

[13] Jiang Boqian, Liu Xin. Evaluation on Efficiency of Water Utilization of Bohal Economic Zone Based on DEA - Malmquist [J]. Resource Development \& Market, 2015,31(01): 49-51. (in Chinese) 